\title{
Description of Trichodina hippoglossi n. sp. from farmed Atlantic halibut larvae Hippoglossus hippoglossus
}

\author{
Frank Nilsen
}

Department of Fisheries and Marine Biology, University of Bergen, Bergen High Technology Center, N-5008 Bergen, Norway

\begin{abstract}
A. new species of Trichodina, T. hippoglossin. sp., collected from skin and fins of farmed Atlantic halibut Hippoglossus hippoglossus (L.), is described. Heavy infections were first evident after a temperature rise from 12 to $18^{\circ} \mathrm{C}$. The most infected specimens were easy to detect due to increased mucus production, which gave the larvae a greyish skin colour. T. hippoglossi is relatively large, $78.5 \pm$ $6.9 \mu \mathrm{m}$ (mean $\pm \mathrm{SD}$; range 65.9 to $89.6 \mu \mathrm{m}$ ), with a denticle ring comprising 28 (mode; range 26 to 30 ) denticles and with a denticle span of $17.6 \pm 1.1 \mu \mathrm{m}$ (mean $\pm \mathrm{SD}$; range 15.7 to $19.2 \mu \mathrm{m}$ ). In silver-impregnated fully grown specimens, a prominent clear central disc is present
\end{abstract}

KEY WORDS: Atlantic halibut Trichodina hippoglossi - New species - Description Morphology

\section{INTRODUCTION}

Trichodinid ciliates are usually considered as harmless ectocommensals on fishes (cf. Lom \& Dyková 1992). However, in aquaculture, with high host densities and abnormal environments, these protozoans may become pathogens and cause mortality. Since the beginning of marine aquaculture there have been several reports of infections with trichodinids. Brøderud \& Poppe (1986) and Sanmartin Duran et al. (1991) have reported infections from turbot Scophthalmus maximus (L.), Jensen (1986) from cod Gadus morhua L. and Moksness et al. (1989) and Moksness (1990) from wolffish Anarhicas lupus L. In none of these reports are the trichodinids involved identified to species.

Lom \& Laird (1969) gave a list of marine trichodinids reported prior to 1969, with an evaluation of their status, i.e. whether they were sufficiently described, poorly described or impossible to recognise ('nomen dubium'). The list contained 5 trichodinid species described from pleuronectiform hosts. Of these, only 2 species were characterised as well established: Trichodina borealis Shulman \& Shulman-Albova, 1953, which has been reported from several flatfish species (e.g. Platichthys flesus L., Hippoglossoides plates- soides Fabr., Pleuronectes platessa L.) (Raabe 1958, Lom \& Laird 1969, MacKenzie 1969, Calenius 1980), and T. raabei Lom, 1962, which has been described from P. flesus in the Black Sea (Lom 1962). Additionally, Pearse (1972) has presented morphometric data for Trichodina sp. from P. platessa from Port Erin, UK.

The aim of the present paper is to describe a new species of Trichodina found on farmed Atlantic halibut Hippoglossus hippoglossus larvae. The species will be compared with previously described Trichodina spp.

\section{MATERIALS AND METHODS}

The halibut larvae originated from a hatchery outside Bergen, Norway. They were kept in tanks with running sea water (salinity $3.4 \%$ ) at $12^{\circ} \mathrm{C}$ for $35 \mathrm{~d}$ after which the temperature was gradually raised to $18^{\circ} \mathrm{C}$. The larvae were used in a challenge experiment with infectious pancreatic necrosis virus (IPNV). Upon arrival at the laboratory the larvae had an average weight of $1.0 \mathrm{~g}$; at the end of the experiment the average weight had increased to $3.0 \mathrm{~g}$.

Air-dried fixed smears, collected by scrapings from fins and skin of the larvae, were treated using Klein's 
dry silver technique (Klein 1958) to reveal the morphology of the adhesive disc. Satisfactory impregnation was difficult to obtain due to the high amount of chloride ions in sea water, which precipitate silver. A modification of the method described by Lom \& Laird (1969) was used. Wet smears were placed on a slide and fixed for 2 min over a flask containing a $5 \%$ solution of boiling formalin. The slide was then placed in a petri dish (15 cm diameter), which was carefully filled with distilled water. After approximately $1 \mathrm{~h}$ the dish was emptied. The preparation was air-dried and impregnated for $8 \mathrm{~min}$ in a $2 \%$ aqueous $\mathrm{AgNO}_{3}$ solution, washed once in distilled water, and exposed to ultraviolet light for 20 to $25 \mathrm{~min}$.

To reveal the nuclear apparatus, air-dried smears were stained in toluidine blue for about $5 \mathrm{~min}$, and then destained in acid-ethanol (1 part $0.1 \mathrm{M} \mathrm{HCl}$ : 9 parts $70 \%$ ethanol) for higher differentiation.

The stained, mounted trichodinids were examined with a stereomicroscope (Leitz, Aristoplan), while the oral ciliation on the body surface was observed in a phase contrast microscope.

Terminology and methods of measurements are as given by Lom (1958) and Van As \& Basson (1989, 1992).

Measurements of the trichodinids were compared using Student's t-test and were considered significant if $\mathrm{p}<0.05$.

\section{RESULTS}

\section{Extent of infection}

The first indication of trichodinid infection was evident after the temperature was raised to between 16 and $18^{\circ} \mathrm{C}$. At this temperature, heavy infections were prevalent and more than 1000 specimens on individual hosts were registered. While no trichodinids were found prior to the increase in temperature, heavy infections (more than 500 specimens per individual host) were found on $21.7 \%$ of the halibuts after the increase. Infections occurred on skin and fins only, and heavily infected halibut larvae were easy to detect due to their greyish skin colour. These specimens also had skin haemorrhages.

\section{Description of Trichodina hippoglossi n. sp. (Figs. 1 to 6)}

Host: Farmed fish, Hippoglossus hippoglossus (L.). Locality: Bergen, Norway.

Site of infection: Skin and fins.

Judging from the large number of post-dividing stages of different age, the infections on the halibut
Table 1. Trichodina hippoglossi n. sp. from Atlantic halibut Hippoglossus hippoglossus. Morphometric data; all measurements are given in $\mu \mathrm{m}$ and are presented as mean $\pm \mathrm{SD}$ (with range in parentheses), except where otherwise noted

$\begin{array}{lc}\text { Location on host } & \text { Skin and fins } \\ \text { Specimens measured }(\mathrm{n}) & 30 \\ \text { Body shape } & \text { Disc } \\ \text { Body diameter } & 78.5 \pm 6.9(65.9-89.6) \\ \text { Diameter, adhesive disc } & 68.7 \pm 6.0(57.8-80.0) \\ \text { Diameter, denticle ring } & 43.0 \pm 4.5(35.2-51.7) \\ \text { Width of border membrane } & 4.9 \pm 1.1(2.5-7.2) \\ \text { Denticle number } & 28^{\circ}(26-30) \\ \text { Radial pins denticle }{ }^{-1} & 12^{\circ}(10-14) \\ \text { Denticle length } & 10.8 \pm 0.8(9.6-12.3) \\ \text { Blade length } & 7.5 \pm 0.7(6.4-8.3) \\ \text { Ray length } & 7.3 \pm 0.7(6.4-8.6) \\ \text { Central part length } & 2.9 \pm 0.8(1.6-4.3) \\ \text { Span of denticle } & 17.6 \pm 1.1(15.7-19.2) \\ \text { Macronucleus shape } & \mathrm{U}-\mathrm{shape} \\ \text { Macronucleus external diameter } & 68.1 \pm 4.2(56.0-72.0) \\ \text { Macronucleus thickness } & 11.8 \pm 1.2(9.6-13.6) \\ \text { Macronucleus X }{ }^{\mathrm{b}} \text { distance } & 19.0 \pm 3.5(14.4-27.2) \\ \text { Micronucleus position } & +y \\ \text { Adoral spiral } & 360-400^{\circ} \\ & \\ \text { aModal value; }{ }^{\circ} \text { as defined by Li \& Desser }(1983)\end{array}$

had a high growth rate. The various developmental stages differed in the size and shape of their adhesive disc components (see Figs. 2 \& 4). To avoid confusion, only specimens with a prominent clear central disc (when silver impregnated) were considered as fully grown and used in the description (see Figs. 1 \& 3).

Morphometric data for Trichodina hippoglossi n. sp. are summarised in Table 1 . The species is relatively large with a disc-shaped body in top view.

\section{Denticle description}

In typical individuals the blade of the denticle fills most of the sector between $y$ and $y+1$ axes. The distal surface is slightly rounded with the tangent point below the distal surface. The blade apex is triangular and typically extends across the $y+1$ axis, with a rounded anterior surface. There is no blade apophysis present. The posterior blade surface is rounded and semilunar, with the deepest point corresponding to the blade apex. The blade connection (i.e. the region where the blade is joined to the central part) is wide, and no posterior projection is present. The central part is rounded, reaching more than halfway to the $y$ - 1 axis (but never touching it), closely fitting the preceding denticle. The sections above and below the $x$-axis are of approximately equal shape and size. There is no indentation in the proximal central part of the denticle. The sector of the central part connected to the ray slants in an anterior proximal di- 


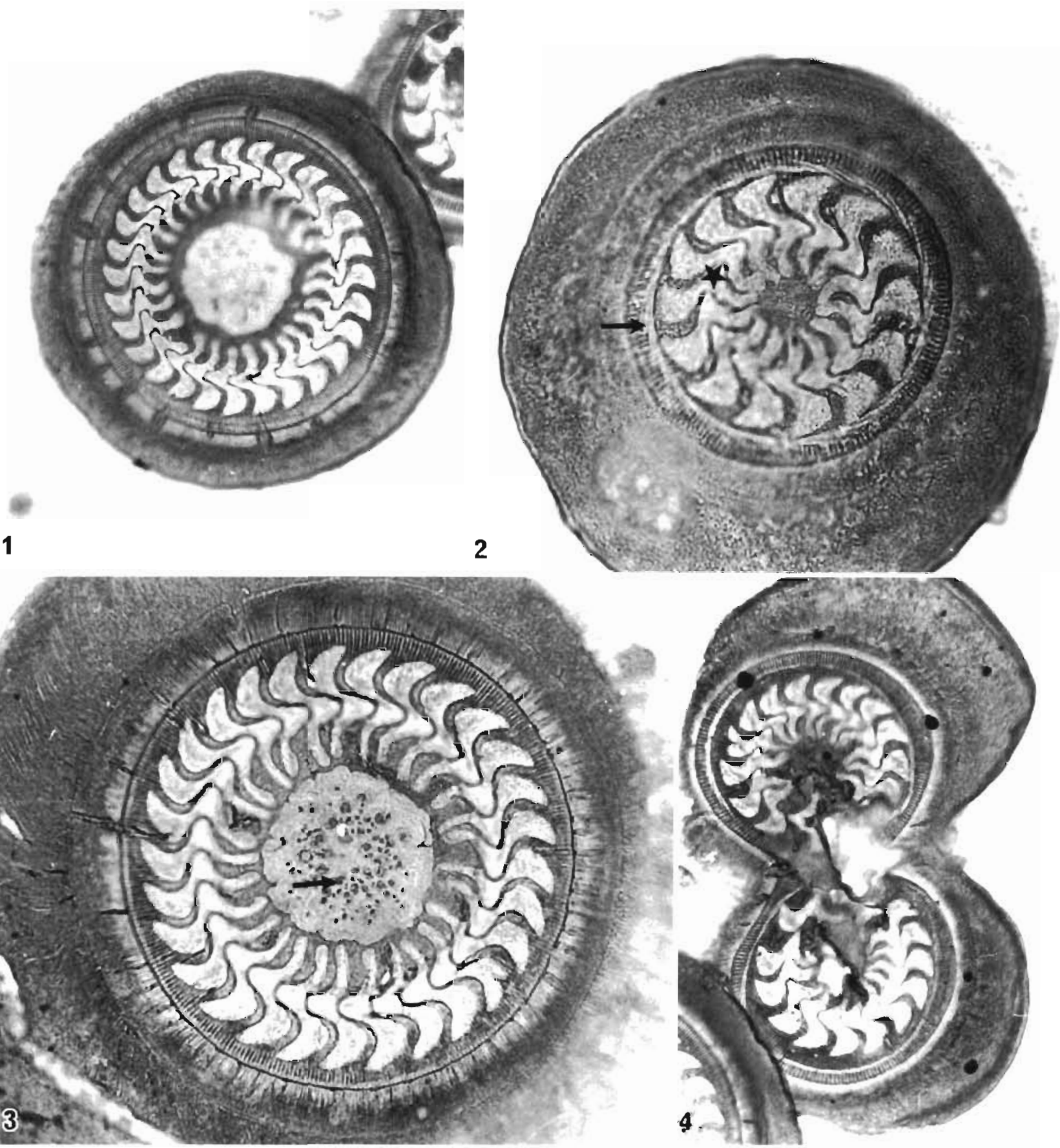

Figs. 1 to 4. Trichodina hippoglossi n. sp. Silver-impregnated adhesive discs. Fig. 1. Mature specimen showing adhesive disc components and a prominent central circle $\times 524$. Fig. 2. Post-dividing stage displaying half the denticle number as in mature specimens and an adhesive disc with a dark centre. Arrow indicates the new denticle ring, asterisk shows the old denticle ring. $\times 918$. Fig. 3. Mature specimen showing argentophile granules in the central circle (arrow). $\times 1084$. Fig. 4 . Specimens in binary division generating individuals of similar size and shape to that in Fig 2. $\times 583$

rection, making an angle larger than $30^{\circ}$ with the $x$-axis, with a robust and thick connection to the ray. Rays are slightly curved, thick and of almost equal thickness throughout, filling a large part of the sector between the $y$ and $y+1$ axes. The ray apophysis is triangular, point- ing anteriorly and situated distally on the ray. The ray point is rounded and does not touch the central circle (see Fig. 5 for drawing of the denticle). There was no significant difference in the span of the ray and blade (Student's $t$-test, $p>0.05$ ). 


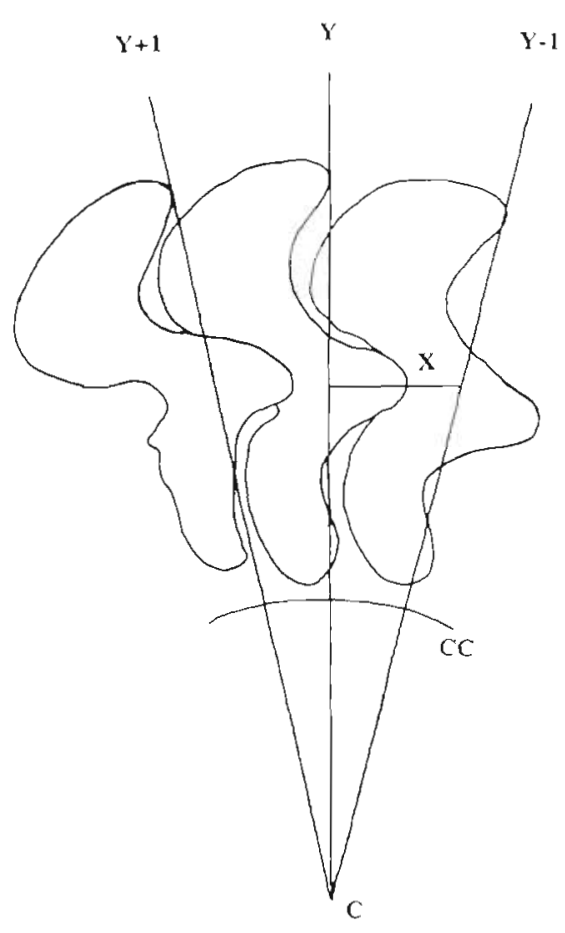

Fig. 5. Trichodina hippoglossin. sp. Drawings of denticles using the method introduced by Van As \& Basson (1989, 1992). $C$ : centre of the adhesive disc; $C C$ : central circle: $X: X$-axis, $Y: y$-axis

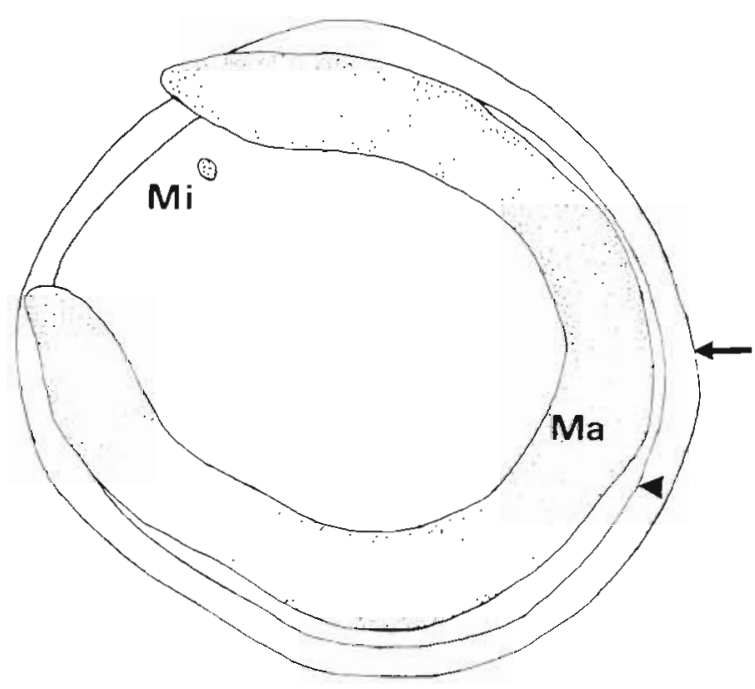

Fig. 6. Trichodina hippoglossi n. sp. Drawing of macro- and micronucleus. The macronucleus is U-shaped and follows the circle of radial pins, with the exception of the outer part of the arms where it extends across the lining of the adhesive disc. The micronucleus is in the $+y$ position. Ma: macronucleus; Mi: micronucleus; arrow indicates the lining of the adhesive disc; arrowhead indicates the lining of the circle with radial pins. $\times 905$
Nuclei

Measurements and drawings of the macro- and micronucleus are given in Table 1 and in Fig. 6 respectively. The macronucleus is U-shaped and follows the circle of the radial pins throughout, with the exception of the outer part of the arms. In this region the macronucleus extends across the lining of the adhesive disc. The micronucleus is located in the $+y$ position (see Fig. 6).

\section{Developmental stages}

Several developmental stages of Trichodina hippoglossi were observed in silver-impregnated smears. The most common were recently divided specimens containing half the number of denticles compared with mature individuals (see Fig. 2). These specimens display an adhesive disc with a darkly stained centre, and a body diameter approximately half that of mature specimens. In dividing specimens the new denticle ring is visible prior to complete division (see Fig. 4).

\section{DISCUSSION}

This is this the first description of a trichodinid from either farmed or naturally accurring Atlantic halibut. Whether the species reported from the other farmed marine fishes are similar to Trichodina hippoglossi n. sp. is at present unknown. However, 3 different species of Trichodina have been described from wild cod (Poynton \& Lom 1989) but none of these is similar to the present species.

Infections with Trichodina hippoglossi were first evident at high temperature (approximately $18^{\circ} \mathrm{C}$ ). This may indicate that $T$. hippoglossi has a relatively high optimum growth temperature, or that this temperature is suboptimal for Atlantic halibut, enabling the parasite to proliferate. Similar observations have been reported for other trichodinids. Lom (1961) and Calenius (1980) observed highest infection rates with trichodinids on freshwater fishes when water temperature was low. Lom (1961) suggested that this could be due to suboptimal conditions for the fish, enabling the parasite to proliferate. In a study of IPNV in Atlantic halibut larvae and fry, Biering et al. (1994) observed significantly higher mortality in fish challenged at $15^{\circ} \mathrm{C}$ than fish challenged at $12^{\circ} \mathrm{C}$. This finding supports the view that larvae and fry of Atlantic halibut are more susceptible to infectious agents at high temperatures (i.e. $15^{\circ} \mathrm{C}$ and up).

A wide variety of Trichodina species with a light central circle have been described from both marine and freshwater fish hosts. From marine fishes there 
are at least 13 known species (see Lom 1962, 1970 , Stein 1973, 1976, 1979, Grupcheva et al. 1989) and some of the previously described species are of similar size to the present species. T. lairdi Lom, 1970, which inhabit the gills of Oligocottus maculosus, possess a light central circle in the adhesive disc and have a similar body diameter. However, there are several features which separate $T$. lairdi from $T$ hippoglossi $\mathrm{n}$. sp. The former has a significantly different denticle shape, i.e. the ray is approximately twice the length of the blade (in the present species no significant difference was observed in the span of the ray and blade). Furthermore, $T$. lairdi have 33 (mode; range 30 to 35 ) denticles in contrast to 28 (26 to 30 ) in T. hippoglossi (cf. Lom 1970).

Trichodina sp. 2 (Grupcheva et al. 1989) possesses a central circle and is of similar size to the present species, but this species has significantly smaller denticles (mean span $12.7 \mu \mathrm{m}$, range 11.1 to $14.4 \mu \mathrm{m}$ ) than $T$. hippoglossin. sp. (see Table 1). In addition, Trichodina sp. 2 has a smaller adhesive disc and denticle ring diameter, and fewer radial pins per denticle.

Trichodina borealis Shulman et Shulman-Albova, 1953 which occurs on the gills of Pleuronectes platessa (and some other species) is considerably smaller than the present species (cf. Lom 1970). Another flatfishinhabiting species, T. raabei Lom, 1962 (from the gills of Pleuronectes flesus luscus), is also smaller and possesses a dark-staining adhesive disc centre (see Lom 1962). Pearse (1972) reported on Trichodina sp. from the skin of captive P. platessa from Port Erin; this species possessed a dark-staining adhesive disc centre and was larger than the present species.

From marine fish hosts, several subspecies of the freshwater species Trichodina domerguei (from skin and fins of stickleback) have previously been described (e.g. Lom 1962). These species all have an adhesive disc with a distinct central circle. T. domerguei f. marisnegri Lom, 1962 from the skin of Gaidropsis mediterranaeus L. possess a light central circle and have an adhesive disc and denticle ring of similar size to the present species. However, there are some distinct differences in the denticle morphology. The former has a larger denticle, and the blade span is larger than the ray. These features, and the larger body diameter of the former, separate these 2 species.

Trichodina murmanica Polyanskii, 1955, a species reported from the skin, fins and gills of several different marine fishes (cf. Poynton \& Lom 1989), possesses a light central circle in the adhesive disc. However, this species can be distinguished from the present species by the notably smaller size of all the adhesive disc components. Additionally, typical specimens of T. murmanica have a significantly longer ray than blade (Nilsen 1993).
Trichodina elegini Shulman-Albova, 1950 from the gills of Eleginus navaga Pallas and T. micromaculata Stein, 1975 from Mugil cephalus L. and Opisthocentrus dybowskii differ from the present species by their considerably smaller size (Stein 1976). In addition, $T$. domerguei f. partidisci Dogiel, 1940, T. domerguei f. indet. Lom, 1962 and $T$. domerguei f. gobii Raabe, 1959, which all have a distinct central circle (Raabe 1958, Lom 1962), are notably smaller than the present species.

To conclude, the present species, Trichodina hippoglossi n. sp., can be differentiated from all previously described Trichodina spp., and is the first species described from Norwegian farmed fish.

Acknowledgements. The author thanks Dr Are Nylund for valuable comments on the manuscript and Stolt Sea Farm for providing the fish.

\section{LITERATURE CITED}

Biering E, Nilsen F, Rødseth OM, Glette J (1994). Susceptibility of Atlantic halibut Hippoglossus hippoglossus to infectious pancreatic necrosis virus. Dis aquat Org 20:183-190

Broderud AE, Poppe TT (1986) Costiasis in farmed turbot (Psetta maxima L.). Norsk Vet Tidsskrift 98:883-884 (in Norwegian)

Calenius G (1980) Parasites of fish in Finland. III. Ciliates of the family Urceolariidae Dujardin, 1851 Acta Acad Abo Ser B 40:1-16

Grupcheva G, Lom J, Dyková I (1989) Trichodinids (Ciliata: Urceolariidaej from gills of some marine fishes with the description of Trichodina zaikai sp. n. Folia Parasitol 36: 193-207

Jensen P (1986) Storing and feeding of brood fish. Norsk Fiskeoppdrett 11:54-55 (in Norwegian)

Klein BM (1958) The dry silver method and its proper use. J Protozool 5:99

Li L, Desser SS (1983) Trichodina algonquinensis, a new species of peritrich ciliate from Ontario freshwater fish, and observations on its transmission. Can J Zool 61:1159-1164

Lom $J$ (1958) A contribution to the systematics and morphology of endoparasitic trichodinids from amphibians, with a proposal of uniform specific characteristics. J Protozool 5: $251-263$

Lom J (1961) Ectoparasitic trichodinids from freshwater fish in Czechoslovakia. Vestn Cesk Spol Zool 25:215-228

Lom J (1962) Trichodinid ciliates from fishes of the Rumanian Black Sea coast. Parasitology 52:49-61

Lom J (1970) Trichodinid ciliates (Peritrichida: Urceolariidae) from some marine fishes. Folia Parasitol 17:113-125

Lom J, Dyková I (1992) Protozoan parasites of fishes. Elsevier, Amsterdam

Lom J, Laird M (1969) Parasitic protozoa from marine and euryhaline fish of Newfoundland and New Brunswick. I. Peritritrichous ciliates. Can J Zool 47:1367-1380

MacKenzie K (1969) Scyphidia (Gerda) adunconucleata n. sp. and Trichodina borealis (Dogiel, 1940) Shulman et Shulman-Albova, 1953 (Protozoa Ciliata) from young plaice in Scottish waters. J Fish Biol 1:239-247

Moksness E (1990) Weaning of wild-caught common wolffish (Anarhichas lupus) larvae. Aquaculture 91:77-85 
Moksness E, Gjøsæter J, Reinert A, Fjallstein IS (1989) Startfeeding and on-growing of wolffish (Anarhichas lupus) in the laboratory. Aquaculture 77:221-228

Nilsen F (1993) On the morphology and some ecological aspects of ectoparasitic trichodinids (Ciliophora: Peritrichia) from saithe (Pollachius virens (L.)). Thesis, University of Bergen

Pearse L (1972) A note on a marine trichodinid ciliate parasitic on the skin of captive flatfish. Aquaculture 1:261-266

Poynton SL, Lom J (1989) Some ectoparasitic trichodinids from Atlantic cod, Gadus morhua L., with a description of Tricodina cooperi n.sp. Can J Zool 67:1793-1800

Raabe Z (1958) On some species of Trichodina (CiliataPeritricha) of gills of Adriatic fishes. Acta Parasitol Pol 6: 355-362

Sanmartin Duran ML, Fernandez Casal J, Tojo JL, Santamarina MT, Estevez J, Ubeira F (1991) Trichodina sp.: effect on the growth of farmed turbot (Scophthalmus maximus).

Responsible Subject Editor: W. Körting, Hannover, Germany
Bull Eur Ass Fish Pathol 11:89

Stein GA (1973) Parasitic ciliates (Pentricha, Urceolariidae) from some fishes of the Barents Sea. Parazitologiya 7 . $489-495$ (in Russian)

Stein GA (1976) Parasitic ciliates (Peritricha, Urceolarudae) of fishes of the White Sea. Acta Protozool 15:447-468 (in Russian)

Stein GA (1979) New data on parasitic ciliates (Peritricha, Urceolariidae) of fishes of the basins of Pacific Ocean. Acta Protozool 18:531-552 (in Russian)

Van As JG, Basson L (1989) A further contribution to the taxonomy of the Trichodinidae (Ciliophora: Peritrichia) and a review of the taxonomic status of some fish ectoparasitic trichodinids. Syst Parasitol 14:157-179

Van As JG, Basson L (1992) Trichodinid ectoparasites (Ciliophora: Peritrichida) of freshwater fishes of the Zambesi River system, with a reappraisal of host specificity. Syst Parasitol 22:81-109

Manuscript first received: August 1, 1994

Revised version accepted: December 13,1994 